\title{
The effect of porphyrins on normal and transformed mouse cell lines in the presence of visible light
} S.P.S. Tita and
J.R. Perussi
Departamento de Q uímica e Física Molecular, Instituto de Q uímica de São Carlos, Universidade de São Paulo, São Carlos, SP, Brasil

\section{Correspondence}

J.R. Perussi

Departamento de Química e

Física M olecular, IQ SC, USP

Av. Dr. Carlos Botelho, 1465

13560-970 São Carlos, SP

Brasil

Fax: + 55-16-273-9985

E-mail: janice@ iqsc.sc.usp.br

Research supported by FAPESP and CNPq. S.P. Silva was the recipient of CNPq and FAPESP undergraduate fellowships.

Received September 11, 2000 Accepted June 18, 2001

\section{Abstract}

Photodynamic therapy consists of the uptake of a photosensitizing dye, often a porphyrin, by tumor tissue and subsequent irradiation of the tumor with visible light of an appropriate wavelength matched to the absorption spectrum of the photosensitizing dye. This class of molecules produces reactive oxygen species when activated by light, resulting in a direct or indirect cytotoxic effect on the target cells. Photodynamic therapy has been used in the treatment of cancer but the technology has a potential for the treatment of several disease conditions mainly because of its selectivity. However, it is not clear why the porphyrins are retained preferentially by abnormal tissue. This paper describes a study of the effect of the association of porphyrin and visible light on two mouse fibroblast cell lines: A31, normal cells and B61, an EJ-ras transformed variant of A31. Two water-soluble porphyrins were used, a positively charged one, tetra(N-methyl-4pyridyl)porphyrin chloride, and a negatively charged one, tetra(4sulfonatophenyl)porphyrin-Na salt $\left(\mathrm{TPPS}_{4}\right)$ in order to assess the effect on cell survival. The results suggest that the $\mathrm{B} 61$ cell line is more sensitive to incubation with the anionic porphyrin $\left(\mathrm{TPPS}_{4}\right)$ followed by light irradiation and that the anionic porphyrin is more efficient in killing the cells than the cationic porphyrin.

\section{Introduction}

Photodynamic therapy (PDT) is a relatively new modality used for cancer treatment, consisting of the combined use of systemically administered photosensitizing porphyrins and local applications of light emitted by lamps or lasers in the presence of oxygen. The technique is based on the preferential accumulation of porphyrin in tumor tissue with subsequent cytotoxicity mediated by singlet oxygen production (1). Its therapeutic usefulness is due to selective and rapid tumor necrosis after illumination of the porphyrin-containing tumor with visible light (2). Tumor necrosis seems to be preceded by significant alterations in the vascular system of the tumor $(1,2)$. Hematoporphyrin derivative $(\mathrm{HpD})$, first developed by Lipson in 1960, and a purified fraction, dihematoporphyrin ether, known as Photofrin $\mathrm{II}^{\circledR}$, are complex mixtures used for tumor localization and treatment (3). Since then, HpD has been applied to endoscopic detection and PDT of various malignant neoplasms including superficial bladder cancer, lung cancer, and cancer of the skin and upper aerodigestive tract (4). HpD has low toxicity and can 
be administered at high doses, having no therapeutic value by itself for treating cancer. However, this dye has photodynamic properties, i.e., in the presence of oxygen and visible light it becomes highly destructive to its immediate environment (5). Porphyrin has been the preferred drug used as a photosensitizing substance due to its high affinity for the tumor cell and its strong effect under irradiation with light (6). Different photosensitizers have been tested for localization in human tumor tissues, including fluorescein, cyanine dyes, porphyrin compounds, eosin, tetracycline, acridine orange and Rhodamine-123 (7). In vivo, the photosensitizer mainly accumulates in organs of the reticuloendothelial system (liver, spleen, kidney, and lungs), atherosclerotic plaques, areas of inflammation and healing wounds (8).

The cationic, meso-substituted porphyrin tetra(N-methyl-4-pyridyl)porphyrin chloride (TMPyP) has been described as a potent photosensitizer in vivo (9) and in vitro (10). This porphyrin is a DNA intercalator in vitro (11) and can photoinduce genotoxic effects in tumor cells in culture (10). Many watersoluble porphyrins form complexes with albumins, the main protein of blood plasma $(12,13)$. Water-soluble porphyrins compete with hydrophobic species for binding sites in albumin, thus increasing the binding of water-soluble porphyrins to membranes and consequently the effectiveness of PDT (14, $15)$. Moreover, the high affinity and phototoxicity of water-soluble sulfonated mesotetraphenylporphyrins $\left(\mathrm{TPPS}_{4}\right)$ themselves for tumor cells allow their consideration as promising compounds for use in PDT (16).

This paper presents the results of a study using two water-soluble porphyrins associated with visible light in two cell lines in order to examine their effect on cell survival. A cationic porphyrin (TMPyP) and an anionic porphyrin $\left(\mathrm{TPPS}_{4}\right)$ were used in their free base form on a normal cell line originating from mouse fibroblasts (A31) and a transformed cell line originating from A31 by transfection (B61). The choice of this class of porphyrins as models is justifiable for this study since one can compare the effect of the charges on the molecules on their cytotoxic effect on cells.

\section{Material and Methods}

\section{Chemicals}

Tetra(N-methyl-4-pyridyl)porphyrin chloride (TMPyP) and tetra(4-sulfonatophenyl)porphyrin-Na salt $\left(\mathrm{TPPS}_{4}\right)$ were purchased from Mid Century Chemicals (Posen, IL, USA). Stock solutions were prepared in water and diluted in Dulbecco's modified Eagle's medium (DMEM) with 1\% FBS just before use.

\section{Cell lines}

The normal cell line used was A31, originating from genetically pure $\mathrm{BALBc} / 3 \mathrm{~T} 3$ mice (17) and consisting of embryo fibroblasts. The transformed cell line B61, also originating from $B A L B c$ mice, was obtained from A31 by transfection of the human EJras oncogene; B61 cells are transformed and tumorigenic (18). The cells were grown in $25-\mathrm{cm}^{2}$ flasks containing DMEM supplemented with $10 \%$ FBS, streptomycin and ampicillin. The cells were kept at $37^{\circ} \mathrm{C}$ and $5 \% \mathrm{CO}_{2}$ and harvested with $0.2 \%$ trypsin + $0.02 \%$ EDTA. Cell viability was assessed by the Trypan blue method.

\section{Cytotoxic assays}

The cells were plated at a density of $10^{2}$ cells $/ \mathrm{ml}$ with DMEM $+10 \%$ FBS onto 35 $\mathrm{mm}$ polypropylene Petri dishes, grown at $37^{\circ} \mathrm{C}$ and $5 \% \mathrm{CO}_{2}$ for $24 \mathrm{~h}$, washed with PBS, and treated with cationic or anionic porphyrin at concentrations ranging from 0 to $30 \mu \mathrm{M}$ for $1 \mathrm{~h}$ at $37^{\circ} \mathrm{C}$. After drug removal, the cells were washed three times with PBS and incubated for several days in ordinary 
supplemented medium until macroscopic colonies could be observed. The cells were then stained with Giemsa and the colonies counted directly on the plates or on a computer screen after scanning the plates.

Effect of the combination of porphyrin and light

The cells were plated in triplicate onto 35-mm polypropylene Petri dishes containing DMEM $+10 \% \mathrm{FBS}$ at a density of $5 \times 10^{4}$ cells $/ \mathrm{ml}$. Cells were grown at $37^{\circ} \mathrm{C}$ for about $48 \mathrm{~h}$ in order to reach a density of about $10^{5}$ cells $/ \mathrm{ml}$. Cells were harvested and counted every day. Immediately before drug addition, three plates were counted. Then the monolayer was washed with PBS and treated with $9 \mu \mathrm{M}$ porphyrin in DMEM $+1 \%$ FBS for $20 \mathrm{~min}$. The cells were washed three times with DMEM $+1 \%$ FBS and ordinary supplemented medium was added. The cells were then exposed to visible light going through a $3-\mathrm{cm}$ high layer of water in order to avoid cell heating. The medium temperature was monitored with a thermocouple. The distance between the cells and the 150W lamp was $13 \mathrm{~cm}$ and the illumination time was $45 \mathrm{~min}$. A blue filter was used to select the wavelength in the range of 500 to 650 $\mathrm{nm}$. The cells were then incubated in triplicate and counted after $30 \mathrm{~min}, 2 \mathrm{~h}, 4 \mathrm{~h}$ and then every day until the time when they were trypsinized, stained with Trypan blue and counted in a hemocytometer. Viability was calculated and viability curves as a function of time were obtained.

\section{Results}

The cytotoxic assays performed with the B61 cell line allowed the determination of the $\mathrm{IC}_{50}$ values for the porphyrins. The $\mathrm{IC}_{50}$ for porphyrins in $\mathrm{B} 61$ cells were $2 \pm 1 \mu \mathrm{M}(\mathrm{N}$ $=3)$ and $5 \pm 1 \mu \mathrm{M}(\mathrm{N}=2)$ for TMPyP and $\mathrm{TPPS}_{4}$, respectively, at pH 7.0 in PBS. The results suggest that the cationic porphyrin is more cytotoxic for this transformed cell line, since its $\mathrm{IC}_{50}$ was about 2.5 -fold lower than the one obtained for the anionic porphyrin.

In order to assess the effect of the combination of porphyrin and light, the growth curves were monitored in the presence of porphyrin with and without illumination. It should be mentioned that, as a control, in all experiments the cells were exposed to light under the same conditions and for the same period of time in the absence of a photosensitizer. No alteration was observed in any of the parameters of the growth curves for either cell line. This was seen as an indication that light by itself does not affect the cells in the absence of a photosensitizer.

Figure 1 presents the growth curves, i.e., the number of cells as a function of time for B61 (A) and A31 (B) cells alone, in the presence of anionic porphyrin and anionic porphyrin associated with light. It was observed that all the parameters of the curve were changed. From the figure, we may assume that the B61 cells will take more time to become confluent after being treated with the drug, a fact that was still more pro-
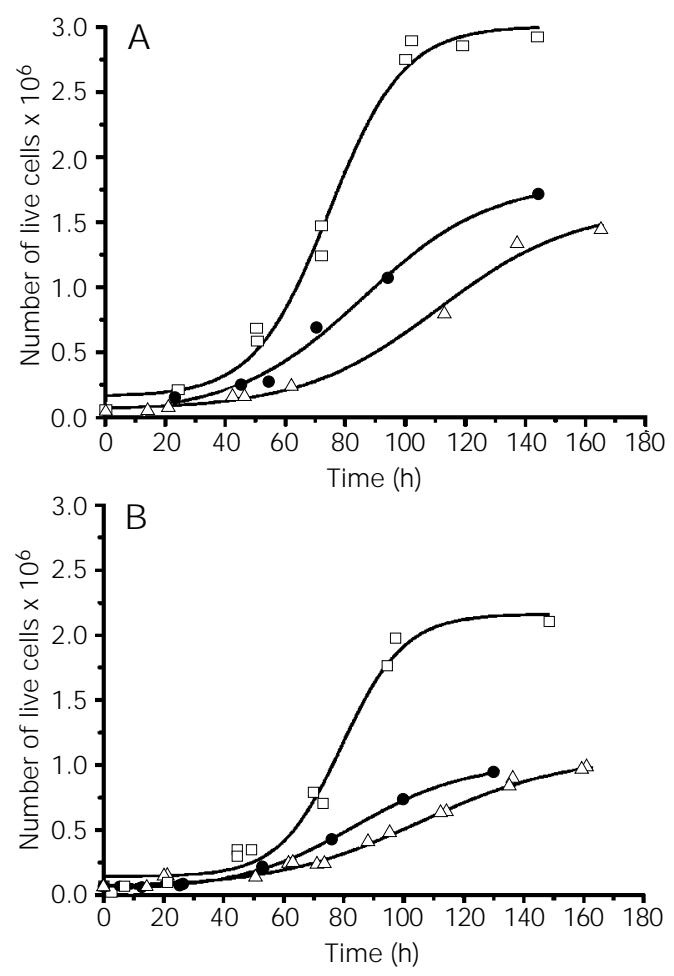

Figure 1. Growth curves for B61 cells (A) and for A31 cells (B) treated with $9 \mu \mathrm{M}$ of anionic porphyrin (TPPS 4 ). Control: cells with no photosensitizer and no light (squares). Cells with photosensitizer and no light (circles); cells with photosensitizer after light irradiation for $45 \mathrm{~min}$ (triangles). 
Figure 2. Viability as a function of time for A31 (squares) and B61 cells (circles) after treatment with the anionic porphyrin $\left(\mathrm{TPPS}_{4}\right)$ and light irradiation.
Figure 3. Growth curves for B61 cells treated with $9 \mu \mathrm{M}$ of cationic porphyrin (TMPyP). Control: cells with no photosensitizer and no light (squares). Cells with photosensitizer and no light (circles); cells with photosensitizer after light irradiation for $45 \mathrm{~min}$ (triangles). nounced in the presence of light. The values for the doubling time were affected after incubation with $\mathrm{TPPS}_{4}$ alone (a $66 \%$ increase for B61 and a 54\% increase for A31) and with light ( 89 and $87 \%$ increases for B61 and $\mathrm{A} 31$, respectively). Viability determined on the basis of the time the cells reached saturation density decreased from 100 to about $66 \%$ in the presence of $\mathrm{TPPS}_{4}$ alone and to $52 \%$ in the presence of $\mathrm{TPPS}_{4}$ plus light for B61. It can be seen that incubation with porphyrin killed about $34 \%$ of B61 cells and incubation with porphyrin plus light killed as much as $48 \%$ of the cells. We may suggest that the toxicity of irradiation not only affected the population of living
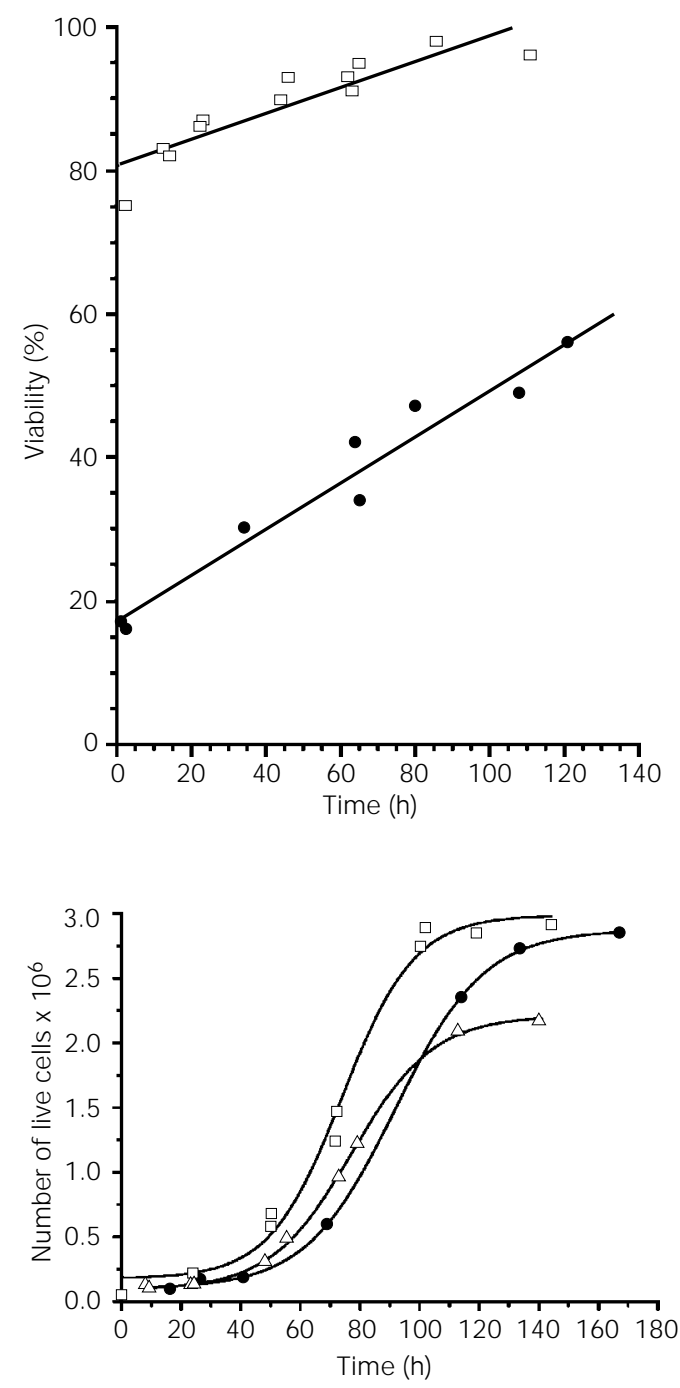

cells but also that the damage continued during growth, preventing the recovery of normal metabolism. These results support the idea that photochemical treatment of the cells greatly increases the efficiency of porphyrin in the control of cell number in a tumor. For the normal A31 cells, cell viability remained high (around 95\%) before and after the treatment and irradiation.

Figure 2 presents cell viability as a function of time for both cell lines after treatment with the anionic porphyrin $\left(\mathrm{TPPS}_{4}\right)$ and light irradiation. From the figure one can see that in fact the cells can recover from treatment to a different extent, but it is quite clear that B61 cells are much more affected and cannot reach more than $50 \%$ of viability even after a long time, while A31 can recover quite well.

Figure 3 shows the effects of the positively charged TMPyP on the growth of B61 cells. These curves suggest that these cells are not very much sensitive to the presence of this porphyrin both as a drug itself or as a photosensitizer, i.e., after irradiation. In the presence of this porphyrin, the log phase had not suffered alteration and the doubling time presented an increase of just $21 \%$ after incubation with porphyrin and about $36 \%$ with light exposure. The viability of B61 cells decreased by $23 \%$ after TMPyP treatment and by $32 \%$ when treatment was combined with light irradiation. Thus, the results show that cationic porphyrin is less cytotoxic than anionic porphyrin both in the dark and after light irradiation.

\section{Discussion}

Both porphyrins used in this study presented a slight toxicity for both cell lines in the dark, i.e., the ability to kill cells in the absence of light when used at therapeutic doses. A relatively low porphyrin concentration was used, $9 \mu \mathrm{M}$ (which corresponds to 7 $\mathrm{mg} / \mathrm{ml}$ for cationic porphyrin and $11 \mathrm{mg} / \mathrm{ml}$ for anionic porphyrin) and the exposure time 
to the porphyrins was only $20 \mathrm{~min}$. It is desirable that the photosensitizer have a high toxicity just after illumination, a parameter that defines the therapeutic effectiveness of the compound. Both porphyrins also meet the conventional requirement for photosensitizers to have a homogeneous chemical composition and high solubility in water, facilitating intravenous administration to the patient.

The viability curve as a function of time for both cell lines after treatment with the photosensitizer and light irradiation clearly showed that in fact transformed and normal cells can recover from treatment to a different extent. It is evident that B61 cells are much more affected by treatment with the anionic porphyrin and cannot reach more than $50 \%$ viability even after a long period of time, while A31 can recover completely.

We may conclude that in the experiments performed with the anionic porphyrin $\left(\mathrm{TPPS}_{4}\right)$ with no light irradiation the more affected cell line was B61 since the doubling time was more affected but cell viability was the parameter showing more sensitivity to the presence of this anionic porphyrin. In the experiments where light exposure was used after porphyrin incubation, B61 was also the more affected cell line.

In the experiments with the cationic porphyrin, the cell line B61 presented only a slight increase in doubling time (36\%) compared to the results obtained for the anionic porphyrin (89\%) after visible light irradiation. The viability determined by the time the cells reached saturation density was about $68 \%$, higher than for $\mathrm{TPPS}_{4}$ in this cell line $(52 \%)$. Thus, these numbers suggest that the B61 cell line is more sensitive to the effects of the anionic porphyrin (TPPS 4 ).

On the basis of the results obtained, we may conclude that, for both cell lines studied, the anionic porphyrin is more efficient in killing the cells as a photosensitizer when incubated for $20 \mathrm{~min}$ and submitted to light irradiation for $45 \mathrm{~min}$. The present results showed that, in fact, there is a considerable decrease in the cell population after porphyrin incubation followed by light irradiation, suggesting that this treatment can be employed as a method to kill tumor cells.

It is well known that PDT leads to apoptosis. However, this event was not investigated in the present study and it is important to say that the approach used here may have a limitation by underestimating the number of affected cells after treatment.

It is interesting to point out that B61 cells (transformed cells) were considerably more affected than A31 cells (normal cells), supporting the hypothesis that porphyrins accumulate rapidly and preferentially in tumor cells. This fact is extremely important for the application of PDT to the treatment of cancer, since the porphyrin is administered intravenously and is supposed to kill only the malignant cells after light irradiation. Thus, the therapeutic usefulness of PDT is based on the preferential accumulation of porphyrin in tumor tissue. To the best of our knowledge, no report in the literature showing this enormous difference in the effect of porphyrin comparing normal and transformed or tumor cell lines has been previously presented.

Our results also suggest that important membrane alterations should take place in the tumor cells causing the selectivity of cell accumulation of the photosensitizing dye that will generate the toxic species leading to cell death.

The results presented here concerning the higher effectiveness of the anionic porphyrin $\left(\mathrm{TPPS}_{4}\right)$ compared with the cationic one (TMPyP) have been confirmed in our laboratory using a human tumor cell line irradiated with laser light.

\section{Acknowledgments}

The authors are grateful to Dr. Mari Sogayar for kindly supplying us with the cell lines, to Mrs. Barbara D. Guedes for technical assistance, and to Dr. Marcel Tabak and Dr. Hidetake Imasato for a critical reading of the manuscript. 


\section{References}

1. Karrer S, Szeimies R-M, Abels C \& Landthaler M (1998). The use of photodynamic therapy for skin cancer. Onkologie, 21: 20-27.

2. Dougherty TJ, Potter WR \& Weishaupt KR (1984). The structure of the active components of haematoporphyrin derivative. In: Andreoni A \& Cubedda R (Editors), Porphyrins in Tumour Phototherapy. Plenum Press, New York, 23-35.

3. Sibata $\mathrm{CH}$, Colussi VC, Oleinick NL \& KinsellaTJ (2000). Photodynamic therapy: a new concept in medical treatment. Brazilian J ournal of Medical and Biological Research, 33: 869-880.

4. Schuitmaker JJ, Baas P, van Leengoed HLLM, van der Meulen FW, Star WM \& van Zandwijk N (1996). Photodynamic therapy: a promising new modality for treatment of cancer. J ournal of Photochemistry and Photobiology. B: Biology, 34: 3-12.

5. Sternberg ED, Dolphin D \& Brucker C (1998). Porphyrin-based photosensitizers for use in photodynamic therapy. Tetrahedron, 54: 4151-4202.

6. Sekiya S, Kubota K, Kasai T, Iwasaki H, Yamauchi $\mathrm{K}$, Takamizawa $\mathrm{H} \&$ Tenjin $\mathrm{Y}$ (1988). Cytocidal effects of hematoporphyrin derivative and argon dye laser on human gynecologic tumor cells in vitro. International J ournal of Gynecology and Obstetrics, 26: 151-158.
7. Haghighat $S$, Castro DJ, Lufkin RB, Fetterman HR, Castro DJ, Soudant J, Ward PH \& Saxton RE (1992). Laser dyes for experimental phototherapy of human cancer: comparison of three rhodamines. Laryngoscope, 102: 81-87.

8. Hamblin MR \& Newman EL (1994). On the mechanism of the tumor localizing effect in photodynamic therapy. J ournal of Photochemistry and Photobiology. B: Biology, 23: 3-8.

9. Villanueva A \& J ori G (1993). Pharmacokinetic and tumour-photosensitizing properties of the cationic porphyrin meso-tetra (4N-methylpyridyl) porphine. Cancer Letters, 73: 59-64.

10. Villanueva A, J uarranz A, Díaz V, Gomez J $\&$ Cañete M (1992). Photodynamic effects of a cationic mesosubstituted porphyrin in cell cultures. Anti-Cancer Drug Design, 7: 297-303.

11. Fiel RJ , Datta-Gupta N, Mark EH \& Howard J C (1979). Interaction of DNA with a porphyrin ligand: evidence for intercalation. Nucleic Acids Research, 6: 30933118.

12. Lamola AA, Asher I, Muller-Eberhard U \& Poh-Fitzpatrick M (1981). Fluorimetric study of the binding of protoporphyrin to hemopexin and albumin. Biochemical J ournal, 63: 693-698.

13. Datta-Gupta N, Malakar D \& Dozier J (1989). Binding studies of 4 free base por- phyrins and 6 iron $(+3)$ porphyrins with human-serum albumin. Research Communications in Chemical Pathology and Pharmacology, 63: 289-292.

14. El-Far MA \& Pimstone NR (1986). Selective in vivo tumor-localization of uroporphyrin isomer-l in mouse mammary carcinoma - superiority over other porphyrins in a comparative study. Cancer Research, 46: 4390-4394.

15. El-Far MA, El-Hamil NA \& Ghoneim M (1988). Selective in vivo localization of heptacarboxylic porphyrin isomer in a bladder tumor model - a novel technique to modulate porphyrin localization. Biochemistry, 70: 1379-1384.

16. Berg K, Bommer J C, Winkelman J W \& Moan J (1990). Cellular uptake and relative efficiency in cell inactivation by photoactivated sulfonated mesa-tetraphenylporphines. Photochemistry and Photobiology, 52: 775-781.

17. Aaronson SA \& Todaro GJ (1968). Development of 3T3-like lines from BALB-C mouse embryo cultures: transformation susceptibility to SV-40. J ournal of Cellular Physiology, 72: 141-148.

18. Kovary K, Armelin MCS \& Armelin HA (1989). HA-RAS-1 oncogene dosage differentially affects BALB/3T3 cells growthfactor requirement and tumorigenicity. Oncogene Research, 4: 55-64. 